Examining the influence of frequent appearance of unknown words and critical thinking on inferencing their meaning

Farahanynia, Mahsa

Alzahra University, Tehran, Iran (M.farahanynia85@yahoo.com)

Nasiri, Morteza

Kharazmi University, Tehran, Iran (Mortezanasiri85@yahoo.com)

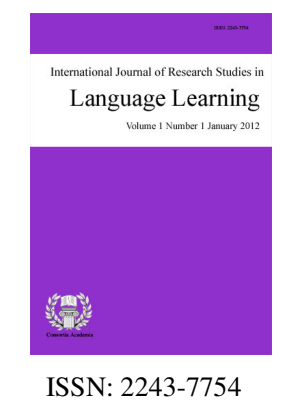

OPEN ACCESS

\title{
Abstract
}

The influence of repetition of an unknown word on incidental vocabulary learning has always been one of the areas that have attracted the attention of researchers in the vocabulary domain. Although different aspects of inferencing have been studied, the relationship between the repetition of an unknown word in the context and the inferencing of its meaning from the context has not been fully studied by researchers. Another point is that inference is one of the sub-skills of critical thinking, and there may be some relationship between critical thinking and lexical inferencing, but no study on this issue has been undertaken. Therefore, the present study was designed to investigate these two relationships. To this end, 68 intermediate learners of English as a Foreign Language participated in this study. They took three inferencing tests which were constructed by the authors of this study. In these tests, the unknown words were repeated once, and three and five times respectively. In order to measure critical thinking ability of the participants, the Persian version of Watson-Glaser Critical Thinking Appraisal (WGCTA) Form A was utilized. The results of repeated-measures ANOVA indicated that the repetition of the unknown words had significant effects on the lexical inferencing. This implies that, as the number of times an unknown word is repeated increases, the probability of the learners' ability to infer its meaning properly increases. It was also found that there is a significant relationship between critical thinking and lexical inferencing.

Keywords: lexical inferencing; critical thinking; repetition; Watson-Glaser critical thinking appraisal; EFL learners; frequency 


\section{Examining the influence of frequent appearance of unknown words and critical thinking on inferencing their meaning}

\section{Introduction}

Researchers have always been interested in how learners learn new words. This interest has opened up two broad lines of research, namely intentional and incidental vocabulary learning. Intentional vocabulary learning involves explicit teaching of vocabulary in the classroom through the use of dictionaries, flash cards, and some other intentional techniques of vocabulary learning (Grabe \& Stoller, 2001). Nation (2001) argues that the first two or three thousand top frequent words of a language should be taught explicitly and beyond this level, words will be learnt incidentally without the need for explicit instruction. It is believed that a great portion of lexical items in L1 and L2 is learnt incidentally (e. g. De Bot, Paribakht, \& Wesche, 1997; Hulstijn, 2003; Nagy \& Anderson, 1984; Paribakht \& Wesche, 1999). Decarrico (2001) describes incidental vocabulary learning as

Learning that occurs when the mind is focused elsewhere, such as on understanding a text or using language for communicative purposes (p. 289).

Paribakht (2005) argues that the first step in incidental vocabulary learning is inferencing; in other words, when learners come across an unknown word, the most commonly used strategy is guessing the meaning of unknown words from the context, which is called lexical inferencing (LI) (De Bot et al., 1997; Paribakht, 2004; Paribakht \& Wesche, 1999). Although different aspects of inferencing have been investigated, it is still open to research.

According to Pearson, Hiebert, and Kamil (2007), what needs further research in the domain of vocabulary is the influence of the number of times an unknown word is repeated (heterogeneity) on the inferencing of its meaning. This is the first concern of the present study. The second concern of this study is the influence of critical thinking (CT) on LI. The rationale behind raising this question has to do with the Delphi study (Faciano, 1990) which was an attempt to define the concept of CT by a panel of experts in different fields of study. They have broken down CT into different skills. One of these skills is inferencing, i.e., to identify elements needed to draw reasonable conclusions, to form conjectures and hypotheses, to consider relevant information, and to draw the consequences flowing from the data, statement, principles, evidence, judgments, beliefs, opinions, concepts, descriptions, questions, or other forms of representations (Facione, 1990), all of which seem to be part of lexical inferencing as well.

\section{Review of the Literature}

\subsection{Lexical inferencing}

Paribakht (2005) argues that the first step in incidental vocabulary acquisition is inferencing. Learners are required to infer the meaning of a word correctly in order to be able to comprehend and produce the word appropriately in the future. If learners associate a word with a wrong inference, not only is there no use in its retention but also it may have some negative consequences. Therefore, inferencing is one of the most important steps in incidental vocabulary learning. Inferencing means to guess the meaning of the unknown word from the context (Haastrup, 1991). Nation (2001) notes that "incidental learning via guessing from context is the most important of all sources of vocabulary learning (p.232)." Some studies (e.g., De Bot et al., 1997; Paribakht, 2004; Paribakht \& Wesche, 1999, Nation 2001) show that when learners come across an unknown word, the most commonly used strategy is guessing the meaning of the unknown word from the context in order to make up for the lack of comprehension. Haastrup (1991) argues 
Influence of frequent appearance of unknown words and critical thinking on inferencing their meaning

[LI] involves making informed guesses as to the meaning of a word in light of all available linguistic cues in combinations with the learner's general knowledge of the world, her awareness of context and her relevant linguistic knowledge (p. 40).

If inferencing is made successfully, as Paribakht and Wesche (1999) argue, it can serve the following purposes: immediate comprehension in reading, listening, interaction or retention.

Various researches have been done to delve into the role of different variables on lexical inferencing. The studies have been done on how much learners are successful in inferring meaning from context (Nist \& Olejnik, 1995; Schatz \& Baldwin, 1986), on the role of proficiency levels (Fraser, 1999; Bengeleil \& Paribakht, 2004), on the role of the clues utilized (Paribakht \& Wesche 2006; Wesche \& Paribakht, 2010), or on the processes of lexical inferencing (Fukkink, 2005). However, to the best of the researchers' knowledge, no study has been conducted to investigate the role of the repetition of the words in the context on the lexical inferencing.

\subsection{Critical thinking}

This study also focused on the relationship between CT (critical thinking) and LI (lexical inferencing). CT is the key principle of Critical Pedagogy (CP) which is related to the concept of power and whose ultimate goal is to empower learners to have a fair community in which learners can achieve their full potential (Kincheloe, 2005). Many scholars (Brown \& Freeman, 2000; Duron, Limbach, \& Waugh, 2006; Hale, 2008; Liaw, 2007; Paul \& Elder, 2005) highlight the significant role of $\mathrm{CT}$ in learning process and its inseparable relationship with education. As Paul and Elder (2005) assert, "Accelerating change, intensifying complexity, escalating interdependence, and increasing danger" (p. 12) are the reasons of its burgeoning significance. However, CT has always been one of the thorny issues in the literature to grasp. Freely and Steinberg (2000) define critical thinking as

the ability to analyze, criticize, and advocate ideas; to reason inductively and deductively; and to reach factual or judgmental conclusions based on sound inferences drawn from unambiguous statements of knowledge or belief (p. 2).

Atkinson (1997) enumerated the characteristics of critical thinkers as follows: truth-seeking, open-mindedness, analytical, systematic, self-confidence, inquisitive, maturity. Nasirahmadi (2014) justifies the relationship between CT and metacognition, creativity, and motivation.

One of the most comprehensive and dependable definitions is provided in the Delphi-study (Facione, 1999). In the Delphi study, 46 experts from different fields come together to define CT. This study used the qualitative research methodology known as the Delphi method which requires the formation of an interactive panel of experts. These experts proposed six cognitive skills and their sub-skills for CT as follows: interpretation (categorization, decoding significance, clarifying meaning), analysis (examining ideas, identifying arguments, analyzing arguments), evaluation (assessing claims, assessing arguments), inference (querying evidence, conjecturing alternatives, drawing conclusions), explanation (stating results, justifying procedures, presenting arguments), self-regulation (self-examination, self-correction).

One of the skills is inference which revolves around identifying and securing elements needed to draw reasonable conclusions; to form conjectures and hypotheses; to consider relevant information and to deduce the consequences flowing from the data, statement, principles, evidence, judgments, beliefs, opinions, concepts, descriptions, questions, or other forms of representations. The first sub-skill is querying evidence which addresses the ability to recognize premises of the argument which are in need of support and gather information. A more general aspect of this sub-skill has to do with judging if more information is needed to support the premises of the argument, and if it is found out that more information is required, some strategies must be determined and employed in order to acquire such information. The next sub-skill is conjecturing alternatives which is the ability to consider the alternatives to solve a problem and to recognize the possible consequences of 
those alternatives. The last sub-skill of inference is drawing conclusions which is self-revealing. These stages can also be involved in lexical inferencing and if some relationship is found between them, by promoting this part of their CT, learners can improve their LI, and consequently, their incidental vocabulary learning.

Some studies have been conducted to detect the role of $\mathrm{CT}$ in various areas of language. Lun, Fischer, and Word (2010) observed European students indicated better CT than Asian ones. Myers and Dyer (2006) found no difference in CT of the males and females. Kamali and Fahim (2011), Sheikhi (2009), Boloori (2010), and Nasirahmadi (2014), investigating the role of CT in reading comprehension with unknown words, reported a significant positive relationship between CT and reading comprehension. Zarei and Haghgoo (2011) found no relationship between $\mathrm{CT}$ and lexical knowledge. All these studies focused on the reading comprehension in general, and none of them exclusively examined the role of CT in lexical inferencing.

\subsection{The novelty of this study}

Most studies undertaken on LI in the realm of second language learning have focused on the ability of the learners in inferencing or the relationship between LI and reading comprehension and, to the best of the researchers' knowledge, no study has conducted on the role of frequency of the unknown word on LI. The present study went beyond this and concentrated on the effect of the degree of critical thinking on lexical inferencing, in other words, the purpose was to see whether high critical thinkers show more success in lexical inferencing.

\subsection{Research Questions}

The abovementioned brief review of LI and CT and the pertinent gaps in the literature sets the ground for raising the following two questions.

- Does the repetition of an unknown word (heterogeneity) influence the inference of its meaning by the learners?

- Does the level of critical thinking influence the inference of the unknown words' meanings?

\section{Method}

\subsection{Subjects}

Ninety (41 male and 49 female) Iranian EFL learners comprised the main participants of the study. They were ranged in age from 20 to 31. During data collection, the participants were studied English at an English Institution in Zanjan, Iran. The proficiency level of the participants was intermediate which was also checked by a TOEFL test.

\subsection{Materials}

A TOEFL-PBT test was used in order to make sure that the participants were at the same level of proficiency. The test consisted of 40 grammar items, 30 vocabulary items, and 30 reading comprehension questions and no listening questions.

Three inferencing tests were administered. The number of items in each test was 20. Test1 (Appendix A) included an unknown word in one sentence. In test2 (Appendix B), one new sentence was added to the first sentence, and the same unknown word was repeated twice in it. In Test 3 (Appendix C), another new sentence was added to the sentences of test 2 , and the same unknown word was repeated twice in it. To put it in other terms, in test1, the unknown word was presented once, in test2, it was repeated three times, and in test3, it was repeated five times. An example of these tests for the unknown word "accomplice" is provided below to clarify this explanation: 
Influence of frequent appearance of unknown words and critical thinking on inferencing their meaning

$>$ Test 1: A. Because he had provided the thief with the weapon, he was arrested as an accomplice in the murder.

$>$ Test 2: A. Because he had provided the thief with the weapon, he was arrested as an accomplice in the murder.

B. Ali could not have done the robbery without an accomplice. After the robbery, he escaped in a stolen car driven by his accomplice.

$>$ Test 3: A. Because he had provided the thief with the weapon, he was arrested as an accomplice in the murder.

B. Ali could not have done the robbery without an accomplice. After the robbery, he escaped in a stolen car driven by his accomplice.

C. One man held a gun on the bank clerk while his accomplice took the money. When his accomplice put the money in the bags they escaped by a fast car.

Finally, the Persian version of version of Watson-Glaser Critical Thinking Appraisal (WGCTA) Form A was used to measure the critical thinking ability of the learners. This CT test was adopted since CT researchers prevailingly utilize it (e.g., Fahim, Bagherkazemi, \& Alemi, 2010; Nasirahmadi, 2014). This 80-item test can be used for the learners in the $9^{\text {th }}$ grade and above. Faravani (2006) states that this translated version is culturally adapted to be used in the Iranian context. The reliability of the test was proved by the test manual $(\alpha=0.81)$. The reliability of the Persian version of this test, translated by Faravani (2006), was estimated to be 0.85 (Nasirahmadi, 2014). The validity of this test (criterion-related, content, and Convergent and Discriminant validities) was also meticulously substantiated by Watson and Glaser (2008).

\subsection{Data collection procedures}

At first, 150 participants were given a test of TOEFL to ensure the homogeneity of the participants. Those who gained the scores in the range of 450-550 were considered to be the intermediate level and served as the participant of this study $(n=130)$.

Afterwards, although WGCTA was proved to be highly reliable and valid (Watson \& Glaser, 2008), in two pilot studies, its reliability and validity were checked. In the first pilot study, it was given to 100 EFL Iranian learners, and the obtained reliability was .87 , which met the satisfactory level. Its criterion-validity was also checked during the second pilot study with 15 participants, which turned out to be .42 . This amount, according to Watson and Glaser (2008), is a satisfactory estimation since it should be above .3. Then, the main participants were given the Persian version of WGCTA to perform in 45 minutes. This determined time is deemed as the standard time required for this test (Nasirahmadi, 2014). Since WGCTA was a multiple choice test, learners had either chosen the right or wrong choice and received 1 or 0 respectively which resulted in a range of scores varying from 0 to 80 . Following its scoring guidelines, those whose percentile rank of total scores were below 40 and above 60 were considered as the learners with Low CT (LCT) $(n=45)$ and the learners with high CT (HCT) $(n=45)$ respectively. Then, the participants in each CT level were randomly assigned to three groups. In other words, each group consisted of 15 low CT and 15 high CT learners. It was done to control the CT variable on LI in each group.

Then, the three inferencing tests were devised. In the selection of words, some points were taken into account. Following Haastrup (1991), all of the words were chosen from the open class only and were unfamiliar to all the pilot-study and main-study participants. In order to ensure that the participants had not known the meaning of the selected words, initially, 25 rather infrequent words of English were chosen. In the third pilot study, the list of words was given to a group of intermediate learners $(n=15)$, similar to the participants of the main study regarding their proficiency level, and they were asked to write their meanings. None of the words were familiar to them. 
Then, the contexts for unknown words were developed. At first, the extra-dictionary-examples part of the Longman dictionary of contemporary English, which comprises several examples from books and newspapers, was used. The examples chosen from this part were modified in order to meet the criterion put forth by Liu and Nation (1985), i.e., the proportion of known to unknown words was about 95 to 5 . In other words, for nineteen known words there was one unknown word. The comprehensibility of the contexts devised for the unknown words were judged by two experts. In cases of disagreement, another context was developed which later on went through the same process.

When the first version of the instrument was ready, the fourth pilot study was carried out. The learners were asked to underline all the words with which they were not familiar, and to try to guess their meaning. Based on the results of this pilot study, two of the items were deleted because they seemed to be easy, and with the help of the context, all of the participants in the pilot study could infer their meanings in test1, and three items were put aside since nobody could guess their meanings even after test3. Finally, 20 items comprised the last version of each inferencing test. 20 unknown words appeared once in the first test, 3 times in the second test, and 5 times in the third test. Test1, test2, and test 3 were administered to group1, group2, and group3 respectively.

\section{Results}

After data collection, the participants' answers to each item was considered as acceptable which received the complete score $(=1)$, partially acceptable $(=5.0)$, or wrong $(=0)$, therefore, their scores varied from 0 to 20 . In order to enhance the interrater reliability, three teachers were asked to score the responses separately, and then in a meeting, they reached a consensus on the scores that were not matched. The first research question addressed the impact of the repetition of unknown words on the lexical inferencing. The descriptive statistics of each inferencing test are presented in Table 1.

\section{Table 1}

Descriptive Statistics of the Inferencing Tests

\begin{tabular}{|c|c|c|c|c|c|}
\hline Group & $\mathrm{N}$ & Minimum & Maximum & Mean & Std. Deviation \\
\hline Test $1^{*}$ & 30 & 2.00 & 10.50 & 7.45 & 2.56754 \\
\hline Test 2 & 30 & 7.50 & 14.50 & 11.03 & 2.12916 \\
\hline Test 3 & 30 & 10.00 & 18.00 & 14.26 & 2.45558 \\
\hline Total & & 2.00 & 18.00 & 10.91 & 3.66447 \\
\hline
\end{tabular}

As seen in Table 1, the highest mean belongs to Test3 (14.26) and the lowest to Test1 (7.45), and the mean of Test2 was 11.03; in other terms, mean $_{\text {Test } 3}>$ mean $_{\text {Test } 2}>$ mean $_{\text {Test1. }}$ In order to see whether these differences in the means were statistically significant or not, a one-way independent-measures ANOVA was conducted. First of all, in order to check the equal variance of the groups on the dependent variable, the homogeneity of the variance was estimated through Levene's test of Homogeneity of Variances. Table 2 presents the results of Levene's test.

\section{Table 2}

Test of Homogeneity of Variances among Groups

\begin{tabular}{cccc}
\hline Levene Statistic & df1 & df2 & Sig. \\
\hline 1.252 & 2 & 87 & .291 \\
\hline
\end{tabular}

Since the level of significance was more than 0.05, as shown in Table 2, the assumption was not violated. Table 3 indicated the results of the one-way ANOVA.

Table 3 indicates that the differences in the means reported in Table 2 were statistically significant, i.e., F (2, $87)=60.997, p<0.05$. To put it in better terms, the repetition factor had a significant effect on the inferencing ability of participants. So as to see where this difference lied, the pair wise multiple comparisons of the tests were run (Table 4). 
Influence of frequent appearance of unknown words and critical thinking on inferencing their meaning

Table 3

The Results of the One-Way ANOVA regarding the Effect of Repetition on Inferencing

\begin{tabular}{lccccc}
\hline & Sum of Squares & df & Mean Square & F & Sig. \\
\hline Between Groups & 697.617 & 2 & 348.808 & 60.997 & .000 \\
Within Groups & 497.508 & 87 & 5.718 & & \\
Total & 1195.125 & 89 & & & \\
\hline
\end{tabular}

Table 4

Pair Wise Multiple Comparisons of Scores in Test1, Test2, and Test3

\begin{tabular}{|c|c|c|c|c|c|c|}
\hline \multirow{2}{*}{$\begin{array}{l}\text { (I) } \\
\text { Group }\end{array}$} & \multirow{2}{*}{$\begin{array}{l}\text { (J) } \\
\text { Group }\end{array}$} & \multirow{2}{*}{$\begin{array}{c}\text { Mean Difference } \\
(\mathrm{I}-\mathrm{J})\end{array}$} & \multirow{2}{*}{ Std. Error } & \multirow{2}{*}{ Sig. } & \multicolumn{2}{|c|}{$95 \%$ Confidence Interval } \\
\hline & & & & & Lower Bound & Upper Bound \\
\hline \multirow{2}{*}{$\mathrm{T} 1$} & $\mathrm{~T} 2$ & $-3.58333^{*}$ & .61744 & .000 & -5.0556 & -2.1111 \\
\hline & $\mathrm{T} 3$ & $-6.81667^{*}$ & .61744 & .000 & -8.2889 & -5.3444 \\
\hline \multirow{2}{*}{$\mathrm{T} 2$} & $\mathrm{~T} 1$ & $3.58333^{*}$ & .61744 & .000 & 2.1111 & 5.0556 \\
\hline & $\mathrm{T} 3$ & $-3.23333^{*}$ & .61744 & .000 & -4.7056 & -1.7611 \\
\hline
\end{tabular}

Note. $*$. The mean difference is significant at the 0.05 level

As seen in Table 4, the improvement of inferencing from test 1 to test 2 and from test 2 to test 3 and test 1 to test 3 were all statically significant, which illustrates that the more times the unknown words were repeated, the more successful the participants were in lexical inferencing. The second question concerns the effect of CT on the inferencing ability. As mentioned before, each group consisted of 15 high CT and 15 low CT learners. Therefore, regarding CT, there were two groups, namely, low CT $(n=45)$ and high CT $(n=45)$. Table 5 reports the descriptive statistics of HCT and LCT Groups' performance in the tests.

Table 5

Descriptive Statistics of the High and Low CT Groups' Performance in the Inferencing Tests

\begin{tabular}{cccccc}
\hline CT & $\mathrm{N}$ & Minimum & Maximum & Mean & Std. Deviation \\
\hline LCT & 45 & 2.00 & 15.00 & 9.07 & 3.29248 \\
HCT & 45 & 7.50 & 18.00 & 12.75 & 3.06672 \\
Total & & 2.00 & 18.00 & 10.91 & 3.66447 \\
\hline
\end{tabular}

As indicated in Table 5, the mean and SD of the HCT group were 9.07 and 3.29 respectively, while the LCT group's mean and SD were 12.75 and 3.06. The mean of the HCT group apparently is greater than mean of the LCT group. In order to see whether this difference was significant or not, one independent samples t-test was run. The results are presented in Table 6.

\section{Table 6}

Results of One Independent Samples T-Test for the High and Low CT Groups' Performance in Inferencing Tests

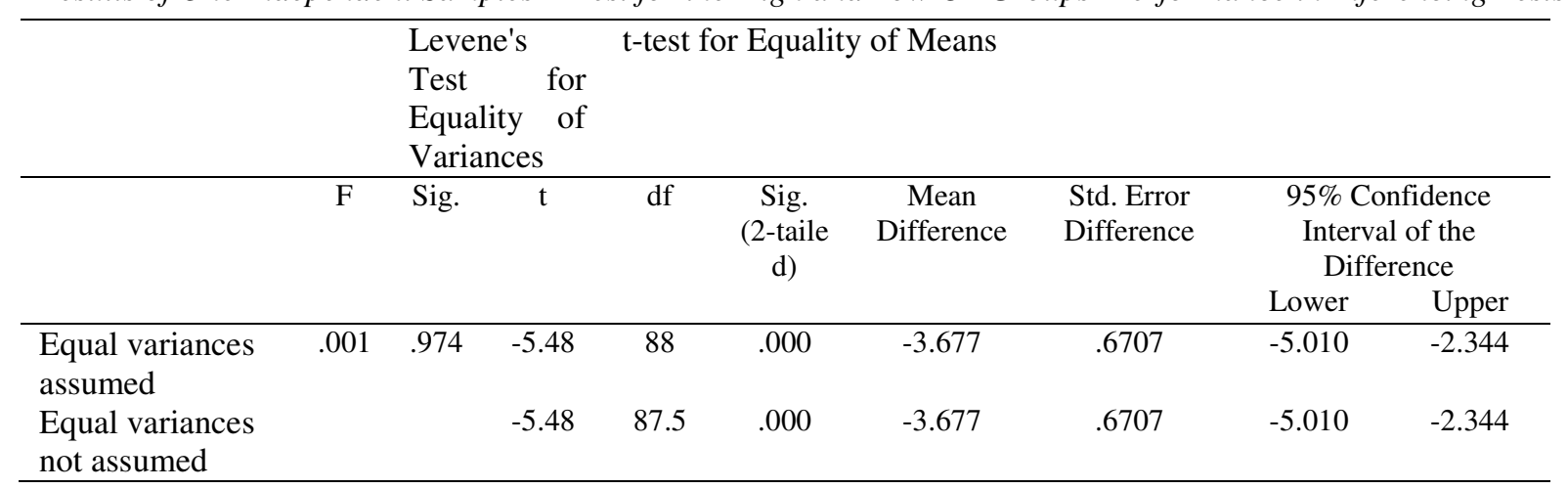

As Table 6 demonstrates Levene's Test for Equality of Variances is insignificant; therefore, the variances between groups is marginal and equal. The results of t-test verify that the difference between the mean of the LCT group and that of the HCT group is significant, i.e., $\mathrm{t}(88)=-5.48, p<.05$. This implies that the HCT group 
with its higher CT ability could significantly perform better in the inferencing tests in comparison with the LCT group.

\section{Discussion}

\subsection{Repetition and lexical inferencing}

The first research question concerned the effect of repeating unknown words in the context on the lexical inferencing. The obtained results suggest that the repetition of unknown words has a significant effect on lexical inferencing, and the more frequently they are repeated in the context, the more successful the learners can be in inferencing. These findings are in line with different studies in the literature such as Webb (2007), Laufer and Yano (2001), Paribakht and Wesche (1999), and Rott (1999).

Ellis (2002) asserts that frequency can propel the activation of the schema in the mind. When coming across some new entity for the first time, learners make an attempt to retrieve the related knowledge sources based on the available cues in the context, such as linguistic source (intra-lingual ones at word, sentence, and discourse levels, and inter-lingual ones) and non-linguistic sources, according to Paribakht and Wesche's (2006) classification of knowledge sources, assess the similarity of the new entity to the exited items in the category in their mind, and establish a weak connection between them. Ellis also asserts "each repetition increases the strength of the connections between the relevant feature units and the category unit" (2002, p. 147), of course, if in each repetition, the learners find evidence of the accuracy of their inference; however, if in the subsequent exposures, they come to the conclusion that their guess has been wrong based on the new available cues, they have another opportunity to infer the meaning of the unknown word and make use of all the cues, i.e., the previous and present ones, which may eventually lead to more successful performance. This process of hypothesis testing can be continued until the most accurate meaning can be derived. Therefore, the repetition of the unknown words can assist the learners to put their guesses into test by being provided with more contextual cues and derive the best meaning.

The positive frequency effect can also be substantiated based on the connectionist theory and competition model. Based on the connectionist theory, each repetition can increase the strength of the existing interconnected nodes, establish new interconnected nodes, or modify the existing ones; in other terms, "the network can change as a result of input frequency" (Ellis, 2008, p. 958). Moreover, competition model concerns "discovering the particular form-function mappings that characterize the target language" (Ellis, 2008, p. 957) and its focus is on the frequency and its positive effects on the establishment of some specific form-function mappings. In the case of lexical inferencing, seeing the unknown words, based on the knowledge sources activated, the learners initially predict some form-function mapping, which may or may not be accurate (a weak interconnected node). If there is no other opportunity for checking the accuracy of their guesses, as was the case with test1 in this study, the learner would cling to that mapping. However, if more cue availability (repetition) and cue reliability (the constant mapping of one form into its function) are provided, the learners can map the form into more accurate functions and strengthen or modify the established interconnected nodes.

In the present study, test 2 and test 3 , in which the unknown word was repeated for three and five times respectively, provided enough cue availability and cue reliability for the learners to establish more accurate form-function mappings and interconnected nodes, in comparison with test 1 in which the unknown word was mentioned only once. Another finding was that the more frequent the unknown word was occurred, the more successful they were in LI. This also corroborates that repetition and frequent occurrence of the words can be deemed as one of the determinant factor in the accurate LI, since it provides opportunities for more and more cue availability and cue reliability, which leads to better form-function mappings. Frequency is also claimed to be a crucial aspect of acquisition, but it was not the concern of this study, and can be a good trigger for future research. 
Influence of frequent appearance of unknown words and critical thinking on inferencing their meaning

The significant improvement brought about by the repetition is also explicable via Levelt's model as discussed in De Bot et al. (1997). Three distinct levels in Levelt's production model are identified, namely, conceptual level (conceptualization), lexeme level (semantic and syntactic information), and lemma level (morphological information). Coming across an unknown word, first of all, the learners, via the initial attention to the form of an unknown word, establish an empty slot for the new lemma in their mental lexicon. According to this view, "the process of inferring meanings of unknown words can be viewed ...... as an attempt to fill in an empty lemma structure" (De Bot et al., 1997, p. 317).

Then, by activating all the cues and knowledge sources available, they activate the lemma in their minds. If the activation of the lemma is a successful one, it can associate the comprehended syntactic information with the conceptual information which, in its own turn, connects the lemma with one or more concepts. So, "the process of inferring the meaning of unknown words is actually one of gathering more information to go from one level to the next" (De Bo et al., 1997, p. 316). It can be stated that in test1, the learners, although maybe activating more than one concept for the unknown words, they had no other evidence for checking their accuracy, so they stick to one of them in random (one-way from the lemma to conceptual levels). However, in test2, they might keep a broader concept of the unknown word in their first exposure, and in the second and third exposure, they put those concepts into test again and again. If their guess was wrong, they again moved from the lemma to conceptual levels and vice versa (a two-way path). The more they go through these paths, the better form-function relationship they could establish, and the more accurate guesses they had. This is evident in test 3 , in which more exposure to the unknown word was available. Of course, this interpretation requires a thicker descriptive analysis of the strategies used by the learners while doing the tasks through think-aloud procedures, which can be another topic for further research.

\subsection{Critical thinking and lexical inferencing}

The second concern of the present study was the relationship between CT and inferencing. The results of the independent samples t-test indicated that the level of CT affected the inferencing ability, meaning that, those who had higher CT ability were significantly better at LI. As inferencing dimension was deemed as one of the sub-categories of CT (Facione, 1990), it was not surprising to obtain such results. A comparison of the CT definition derived in a Delphi-study definition and LI shows that the two of them have some features in common. Just like the inferencing dimension of CT, LI deals with conjectures and hypotheses (as explicated above) and considers relevant information in its context in order to solve the problem of not knowing a word, and the guess made in LI can be considered as a kind of reasonable conclusion and solution to the problem. But inference is not the only skill in Facione (1990) which pertains to LI, other skills, such as interpretation, analysis, evaluation, and self-regulation are also involved in LI. When a reader wants to guess the meaning of an unknown word, s/he interprets and analyses the immediate context, and makes a guess, then he may evaluate his/her own guess via hypothesis testing, and, if not satisfied, self-corrects which is a sub-skill in self-regulation. Therefore, it can be stated that there is a close connection between the dimensions of CT and the strategies used by the learners in lexical inferencing; so, high CT would result in greater LI. Or maybe similar cognitive abilities are required for both, as Kamali and Fahim (2011) concluded "critical thinking and reading are both cognitive abilities which have some identifiable cognitive skills in common" (p. 110), and one aspect of successful reading is to have the good ability to guess unknown words' meaning correctly (Wesche \& Paribakht, 2010).

This finding is in consonant with Kamali and Fahim (2011), Koupaee Dar, Rahimi, and Shams (2010), Boloori (2010), Mirzai (2008), and Nasirahmadi (2014), all of whom found the significant effect of CT on L2 performance. Frisby (1992) and Jacobs (1995) found a strong relationship between CT and the US school achievement test (SAT). In the same line of research, Yeh and Wu (1992) reported a high correlation coefficient of about 0.46 and effect sizes larger than 1 between CT and mathematics. Giancarlo and Facione (2001) found a significant correlation between students' GPA and their CT level. Since inferencing results in incidental vocabulary learning, and incidental vocabulary learning contributes to school achievement, it is possible to claim that the results of present study are in line with Frisby (1992), Jacobs (1995), Yeh and Wu (1992), Giancarlo and 
Facione (2001) as well. In the same vein, Jamshidian Ghaje Sefidi (2010) found a strong relationship between $\mathrm{CT}$ and detecting ambiguities in ambiguous sentences.

It is worth noting that most of the researchers (such as Alagozlu, 2007; Lun et al., 2010; Zarei \& Haghgoo, 2012) declare that the Asian students, including Iranian students, have significantly different critical abilities in comparison with Western students due to the cultural differences. These learners are considered not to grow up in a way to be strong enough to activate the satisfactory levels of CT and are required to be supported and taught in this regard. Zarei and Haghgoo (2012), specifically mentioning the Iranian context, detect its root in the traditional educational system which is more teacher-fronted and conformity-oriented, and call for some modification in the system. The results of this study also pinpoint the importance of critical thinking and its effect on one aspect of second language learning (lexical inferencing) and the need for improving CT of the leaners in Iran in order to enhance their capability of learning.

\section{Conclusion and practical implications}

This study was undertaken to delve into the role of repetition on LI. The second concern of the study was the impact of CT on LI. It was found that the number of the repetition of unknown words had a significant effect on the success in LI. This significant effect was explained through various EFL models, i.e., competition model, connectionist theory, and Levelt's lexical hypothesis. Therefore, it can be concluded that the more the learners are exposed to the unknown words, the more accurate the inferencing is. Regarding CT and LI, it was concluded that in both, learners go through more or less the same set of cognitive skills and strategies and the improvement in CT can bring about more successful LI, which in turn can enhance the reading skill (Kamali \& Fahim, 2011) as one of the most important skills, especially in academic settings.

These results are of value due to its practical implications. As results indicated, frequency and repetition are of paramount importance in the process of lexical inferencing, so it is up to the teachers to provide such opportunities in the class via repeating the new words in different context, even in their own speech during the class and assist the learners in the game of guessing the meaning. The significance of such repetition and frequency augments in the foreign language context, such as Iran, in which such exposure confides to the classroom, and therefore, is very limited.

The importance of CT and its effect on cognitive ability, in general, and its relation to LI in particular were highlighted in this study. Consequently, it is essential for the L2 teachers to include CT in their teaching plans for the purpose of enhancing the students' "inquiry, problem solving, critical and creative thinking, and reflection which can contribute to their progress in language learning" (Kamali \& Fahim, 2011, p.110). Some suggestions have been provided for CT teaching. Teachers can use the four-part model of Helpern (1998) which is

a) a dispositional or attitudinal component, b) instruction in and practice with CT skills, c) structure-training activities designed to facilitate transfer across contexts, and d) a metacognitive component used to direct and assess thinking (p. 451).

Another model useful for teaching CT is the five-step model proposed by Duron et al., (2006) through which teachers can lead students toward CT. The steps are in the following order: a) determining learning objectives, b) teaching through questioning, c) practicing before assessing, d) reviewing, refining, and improving, e) providing feedback and assessing learning. In the same respect, they claim that questioning has a vital role in their model since learners learn by questioning and this questioning should be guided by teachers, although, "this is understandably difficult and takes commitment" (Duron et al., 2006, p. 162).

Teacher trainers should also direct more attention to CT teaching, and try to improve prospective teachers' critical thinking first, and then teach them how to promote it in their students. The results also inform syllabus designers and material developers who are responsible for the incorporation of the activities and tasks which provoke the greater use of CT and develop this significant ability, especially in learning contexts in which such 
opportunity is not available due to cultural and educational constraints.

Acknowledgments: The researchers would like to thank the learners served as the participants of this study for their cooperation.

\section{References}

Atkinson, D. (1997). A critical approach to critical thinking in TESOL. TESOL Quarterly, 31(1), 71-94. http://dx.doi.org/10.2307/3587975

Alagozlu, N. (2007). Critical thinking and voice in EFL writing. Asian EFL Journal, 9(3), 118-136.

Bengeleil, N. F., \& Paribakht, T.S. (2004). L2 reading proficiency and lexical inferencing by university EFL learners. The Canadian Modern Language Review, 61(2), 225-249. http://dx.doi.org/10.3138/cmlr.61.2.225

Boloori, L. (2010). The relationship between critical thinking and performance of Iranian EFL learners on the inferential reading comprehension test. Unpublished Masteral thesis, Azad University of Takestan, Iran.

Brown, M. N., \& Freeman, K. (2000). Distinguishing the features of critical thinking classrooms. Teaching in Higher Education, 5(3), 301-309. http://dx.doi.org/10.1080/713699143

De-Bot, K., Paribakht, T. S., \& Wesche, M. B. (1997). Toward a lexical processing model for the study of second language vocabulary acquisition: Evidence from ESL reading. Studies in Second Language Acquisition 19, 309-329. http://dx.doi.org/10.1017/s0272263197003021

Decarrico, J. S. (2001). Vocabulary learning and teaching. In M. Celce-Murcia (Ed.), Teaching English as a second or foreign language ( $3^{\text {rd }}$ ed., pp. 285-299). US: Heinle \& Heinle.

Duron, R., Limbach, L., \& Waugh., W. (2006). Critical thinking framework for any discipline. International Journal of Teaching and Learning in Higher Education, 17(2), 160-166.

Ellis, N. C. (2002). Frequency effects in language processing: A review with implications for theories of implicit and explicit language acquisition. Studies in Second Language Acquisition, 24, 143-188. http://dx.doi.org/10.1017/s0272263102002024

Ellis, R. (2008). The study of second language acquisition. Oxford: Oxford University Press.

Facione, P. A. (1990). Critical thinking: a statement of expert consensus for purposes of educational assessment and instruction. Executive summery. Eric paper no. ED 315-423.

Fahim, M., Bagherkazemi, M., \& Alemi, M. (2010). The relationship between test takers' critical thinking ability and their performance on the reading section of TOEFL. Journal of Language Teaching and Research, 1(6), 830-837. http://dx.doi.org/10.4304/jltr.1.6.830-837

Faravani, A. (2006). Investigating the effect of reading portfolio on the Iranian students' critical thinking ability and reading achievement. Unpublished Masteral thesis, Ferdowsi University, Iran.

Fraser, C. (1999). Lexical processing strategy use and vocabulary learning through reading. Studies in Second Language Acquisition, 21, 225-241. http://dx.doi.org/10.1017/s0272263199002041

Freely, A. J., \& Steinberg, D. L. (2000). Argumentation and debate: Critical thinking for reasoned decision-making. Stamford: Wadsworth.

Frisby, C. L. (1992). Construct validity and psychometric properties of the Cornell Critical thinking test (level z): a contrasted groups analysis. Psychological reports, 71, 291-303. http://dx.doi.org/10.2466/pr0.1992.71.1.291

Fukkink, R. G. (2005). Deriving word meaning from written context: a process analysis. Learning and Instruction, 15, 23-43. http://dx.doi.org/10.1016/j.learninstruc.2004.12.002

Giancarlo, C. A., \& Facione, P. A. (2001). A Look across four years at the disposition toward critical thinking among undergraduate students. The Journal of General Education, 50(1), 29-55. http://dx.doi.org/10.1353/jge.2001.0004 
Farahanynia, M., \& Nasiri, M.

Grabe, W., \& Stoller, F. L. (2001). Reading for academic purposes: Guidelines for EFL/ESL teacher. In M. Celce-Murcia (Ed.), Teaching English as a second or foreign language ( $3^{\text {rd }}$ ed., pp. 187-203). Heinle \& Heinle.

Hale, S. (2008). A critical analysis of Richard Paul's substantive tran-disciplinary conception of critical thinking. Unpublished Doctoral dissertation, Union University of Cincinnati, Ohio.

Hasstrup, K. (1991). Lexical inferencing procedure or talking about words. Tubingen: Gunter.

Helpern, D. F. (1998). Teaching critical thinking for transfer across domains: dispositions, skills, structure training, and metacognitive monitoring. American psychologist, 53(4), 449-455. http://dx.doi.org/10.1037/0003-066X.53.4.449

Hulstijn, J. H. (2003). Incidental and intentional learning. In C. Doughty, \& M. H. Long (Eds.), The handbook of second language acquisition (pp. 349-381). UK: Blackwell Publishing. http://dx.doi.org/10.1002/9780470756492.ch12

Jacobs, S. S. (1995). Technical characteristics and some correlates of the California critical thinking skills test forms A and B. Higher Education Research, 36, 89-108. http://dx.doi.org/10.1007/BF02207768

Jamshidian Ghale Sefidi, T. (2010). Grammatical ambiguity and critical thinking. Unpublished Doctoral dissertation. University of Tehran, Tehran.

Kamali, Z., \& Fahim, M. (2011). The relationship critical thinking ability of Iranian EFL learners and their resilience level facing unfamiliar vocabulary items in reading. Journal of Language Teaching and Research, 2(1), 104-111. http://dx.doi.org/10.4304/jltr.2.1.104-111

Kincheloe, J. L. (2005). Critical constructivism. New York, NY: Peter Lang.

Koupaee Dar, Z., Rahimi, A., \& Shams, M. R. (2010). Teaching reading with a critical attitude: using critical discourse analysis to raise EFL university students' critical language awareness. International Journal of Criminology and Sociology, 3(2), 457-476.

Laufer, B., \& Yano, Y. (2001). Understanding unfamiliar words in a text: Do L2 learners understand how much they don't understand?' Reading in a Foreign Language, 13(2), 549-66.

Liaw, M. (2007). Content-based reading and writing for critical thinking skills in an EFL context. English Teaching and Learning, 31(2), 45-87.

Liu, N., \& Nation, I. S. P. (1985). Factors affecting guessing vocabulary in context. RELC Journal, 16, 33-42. http://dx.doi.org/10.1177/003368828501600103

Lun, V. M., Fischer, R., \& Ward, C. (2010). Exploring cultural differences in critical thinking: Is it about my thinking style or the language I speak? Learning and Individual differences, 20, 604-616. http://dx.doi.org/10.1016/j.lindif.2010.07.001

Mirzai, Z. (2008). The relationship between critical thinking and lexical inferencing of Iranian EFL learners. Unpublished Masteral thesis, Azad University of Science and Research, Tehran, Iran.

Myers, B. E., \& Dyer, J. E. (2006). The influence of student learning style on critical thinking skill. Journal of Agricultural Education, 47(1), 43-52. http://dx.doi.org/10.5032/jae.2006.01043

Nagy, W. E., \& Anderson, R. C. (1984). How many words are there in printed school English? Reading research quarterly, 19, 304-330. http://dx.doi.org/10.2307/747823

Nasirahmadi, A. (2014). The relationship between Iranian language learners' critical thinking ability and their reading comprehension achievement. International Journal of Research Studies in Language Learning, 3(7), 15-27. http://dx.doi.org/10.5861/ijrsll.2014.689

Nation, I. S. P. (2001). Learning vocabulary in another language. Cambridge: Cambridge University Press. http://dx.doi.org/10.1017/CBO9781139524759

Nist, S. L., \& Olejnik, S. (1995). The role of context and dictionary definitions on varying levels of word knowledge. Reading Research Quarterly, 30(2), 172-193. http://dx.doi.org/10.2307/748031

Paribakht, T. S. (2004). The role of grammar in second language learning processing. RELC, 35(2), 149-160. http://dx.doi.org/10.1177/003368820403500204

Paribakht, T. S. (2005). The influence of L1 lexicalization on L2 lexical inferencing: A study of Farsi-speaking EFL learners. Language Learning, 55(4), 701-748. http://dx.doi.org/10.1111/j.0023-8333.2005.00321.x

Paribakht, T. S., \& Wesche, M. (1999). Reading and incidental L2 vocabulary acquisition. An introspective study 
Influence of frequent appearance of unknown words and critical thinking on inferencing their meaning

of lexical inferencing. Studies in Second Language Acquisition, 21, 195-218. http://dx.doi.org/10.1017/S027226319900203X

Paribakht, T. S., \& Wesche, M. (2006) Lexical inferencing in L1 and L2: Implications for vocabulary instruction and learning at advanced levels. In H. Byrnes, H. Weger-Guntharp, \& K. Sprang (Eds.), Educating for advanced foreign language capacities: Constructs, curriculum, instruction, assessment (pp. 118-135). Washington, DC: Georgetown University Press.

Paul, R., \& Elder, L. (2002). Critical thinking: Tools for taking charge of your professional and personal life. Dillon Beach, CA: Foundation for Critical Thinking.

Pearson, P. D., Hiebert, E. H., \& Kamil, M. L. (2007). Vocabulary assessment: What we know and what we need to know. Reading Research Quarterly, 42(2), 282-296. http://dx.doi.org/10.1598/RRQ.42.2.4

Rott, S. (1999). The effect of exposure frequency on intermediate language learners' incidental vocabulary acquisition through reading. Studies in Second Language Acquisition, 21, 589-619. http://dx.doi.org/10.1017/S0272263199004039

Schatz, E. K., \& Baldwin, R. S. (1986). Context clues are unreliable predictors of word meanings. Reading Research Quarterly, 21, 439-453. http://dx.doi.org/10.2307/747615

Sheikhi, B. R. (2009). The relationship between Autonomy, Critical thinking and Reading comprehension of Iranian EFL learners. Unpublished Masteral thesis, Azad University of Science and Research, Tehran, Iran.

Watson, G., \& Glaser, E. M. (2008). Watson-Glaser Critical Thinking Appraisal. United States: Pearson Education Inc.

Webb, S. (2007). The effects of repetition on vocabulary knowledge. Applied Linguistics, 28, 46-65. http://dx.doi.org/10.1093/applin/aml048

Wesche, M., \& Paribakht, T. S. (2010). Lexical inferencing in a first and second language: Cross-linguistic dimensions. Bristol: Multilingual Matters.

Yeh, Y. C., \& Wu, J. J. (1992). The relationship between critical thinking and academic achievements among elementary and secondary school students. Journal of Education and Psychology, 15, 79-100.

Zarei, A. A., \& Haghgoo, E. (2011). The relationship between critical thinking and L2 grammatical and lexical knowledge. English Linguistics Research, 1(1), 104-110. 
Appendices

Appendix A: The first inferencing test (Test1)

Name ............... Level .............. Age..............Gender...........

Please read the sentences carefully and try to guess the Farsi meaning of bold words.

1. Because he had provided the thief with the weapon, he was arrested as an accomplice in the murder. Accomplice

2. Two of her toes were amputated because of being frozen in the North Pole Amputate

3. How can you be so apathetic about the world and its problems? Don't you have emotion? Apathetic

4. His explanations about the problematic situation resulted only in befuddling her more. Befuddling

5. He would brook no criticism, even from his beloved daughter.

Brook

6. In the capacious areas of the railroad terminal, thousands of travelers were waiting for their trains. Capacious

7. Ali was fired from work and was very despondent.

Despondent

8. He is very good at playing roles; he can feign any feeling like sadness, happiness, and surprise.

Feign

9. It is a very onerous job to work from 8 in the morning till 10 in the evening.

Onerous

10. After an argument the upshot was that they all agreed to help her pay back her debt.

Upshot . . .

11. The ultimate champion of the boxing competition will be clear tonight, because tonight is the final match. Champion

12. He is really voluble. He can talk for hours without stopping.

Voluble

13. She was absolutely livid that he had lied to her.

Livid

14. Many people loathe the smell of fish and cannot tolerate it.

Loathe .

15. What vexed him most was that nobody had apologized to him, although he was right and others had made a mistake. Vex

16. Hossein is a very tenacious person; he tries his best to achieve what he wants, even if it is so difficult. Tenacious

17. In the war between Iran and Iraq a lot of houses were obliterated in the south west of Iran.

Obliterate ....

18. She's too parsimonious to give money to charity.

Parsimonious

19. As I drove home, I tried to think how I was going to pacify my wife, who was angry with my decision about not going to her parents' home for dinner.

Pacify

20. The president is chosen by people from among Contenders.

Contender 


\section{Appendix B: The second inferencing test (Test2)}

Name Level

Age.

Gender.

Please read the sentences carefully and try to guess the Farsi meaning of bold words.

1. A. Because he had provided the thief with the weapon, he was arrested as an accomplice in the murder.

B. Ali could not have done the robbery without an accomplice. After the robbery, he escaped in a stolen car driven by his accomplice.

Accomplice

2. A. Two of her toes were amputated because of being frozen in the North Pole.

B. He damaged his leg so badly that it had to be amputated after the accident. Having a leg amputated, he was really depressed for months. Amputate

3. A. How can you be so apathetic about the world and its problems? Don't you have emotion?

B. Some people are so apathetic that they do not pay attention to things which happen in the society. Maybe they think that when they are apathetic, they can live more happily.

Apathetic

4. A. His explanations about the problematic situation resulted only in befuddling her more.

B. I understand the text but the numbers are befuddling me. I think the numbers and the text are explaining different things; that is why the numbers are befuddling.

Befuddling

5. A. He would brook no criticism, even from his beloved daughter.

B. I cannot brook any noise when I am studying. Because I cannot brook any noise while I am studying and get distracted even with a little noise, I usually study at the library which is so quiet.

Brook

6. A. In the capacious areas of the railroad terminal, thousands of travelers were waiting for their trains.

B. It is a capacious theater; hundreds of people can come and watch different plays. The theatre is capacious, so it is never completely filled even on holydays with hundreds of people.

Capacious

7. A. Ali was fired from work and was very despondent. B. Sarah lost her father a year ago in an accident, but she is still despondent. When Sarah lost her father, she was so despondent that she could not eat food for two or three days.

Despondent

8. A. He is very good at playing roles; he can feign any feeling like sadness, happiness, and surprise.

B. She had an exam and was not ready; therefore, she decided to feign illness and stay at home.

The next day that she went to school, she still had to feign that she is sick and had not recovered fully.

Feign

9. A. It is a very onerous job to work from 8 in the morning till 10 in the evening.

B. He always complained that his job was so onerous and he had to do a lot from 8 a. m. to 6 p.m. Last month he asked for an assistant because his work load was too onerous and he could not do it alone, for example he had to answer a lot of phone calls, write many emails and supervise workers in the factory all by himself.

Onerous ......

10. A. After an argument the upshot was that they all agreed to help her pay back her debt.

B. The upshot of the interview was that he could work in the company for another year.

Another upshot was that if during this year he worked well, he would be an official member of the company; otherwise he had to leave after a year.

Upshot

11. A. The ultimate champion of the boxing competition will be clear tonight, because tonight is the final match.

B. The ultimate failure of the project shocked all the researchers in the company. The researchers concluded that the ultimate outcome of the experiment could not be predicted........

12. A. He is really voluble. He can talk for hours without stopping.

B. Some people believe that it is rude to be voluble, because when a person is voluble, other people cannot find time to talk.

Champion

13. A. She was absolutely livid that he had lied to her.

B. He was so livid that he tore the letter and started shouting. Later when I asked him why he got livid, he answered that there was something insulting in the letter that made him lose his control.

Livid

14. A. Many people loathe the smell of fish and cannot tolerate it.

B. Some men loathe shopping, because it makes them really tired to walk from one store to another. But most of women are in love with shopping and cannot understand why some men loathe it.

Loathe ..... 
Farahanynia, M., \& Nasiri, M.

15. A. What vexed him most was that nobody had apologized to him, although he was right and others had made a mistake. B. It vexes me that Kim never returns the books she borrows. And what vexes me more is that I have asked her several times to return the books she has borrowed, and each time she says: "ok", but she does not.

Vex ....................

16. A. Hossein is a very tenacious person; he tries his best to achieve what he wants, even if is so difficult.

B. Right two months before his university entrance exam, his father died, but because he is a tenacious person he did not stop studying and passed the exam successfully. When people asked him how he could pass the exam in such a difficult time, he said the only secret to success is tenacity.

Tenacious

17. A. In the war between Iran and Iraq a lot of houses were obliterated in the south west of Iran.

B. Many Japanese people's houses were obliterated after the latest earthquake and they became homeless. What made it even worse was that their factories and roads were obliterated by tsunami.

Obliterate

18. A. She's too parsimonious to give money to charity.

B. Usually when people get old, they become parsimonious and love money, and some old people become even too parsimonious to spend money for their medicine.

Parsimonious

19. A. As I drove home, I tried to think how I was going to pacify my wife, who was angry with my decision about not going to her parents' for dinner.

B. He had a fight with his boss and was angry. I wanted to talk to him and pacify him, but as I started to talk I understood he was too angry to be pacified by talking, then I left him alone for a while. Sometimes the only thing which is needed to calm down is time.

Pacify

20. A. The president is chosen by people from among Contenders.

B. First some movies are chosen as Contenders for Oscar, and then from among the Contenders, one of them is chosen as the best one to get the Oscar.

Contender....

\section{Appendix $C$ : The third inferencing test (Test3)}

Name Age

Level

Gender

Please read the sentences carefully and try to guess the Farsi meaning of bold words.

1. A. Because he had provided the thief with the weapon, he was arrested as an accomplice in the murder.

B. Ali could not have done the robbery without an accomplice. After the robbery, he escaped in a stolen car driven by his accomplice.

C. One man held a gun on the bank clerk while his accomplice took the money. When his accomplice put the money in the bag, they escaped by a fast car.

Accomplice......

2. A. Two of her toes were amputated because of being frozen in the North Pole.

B. He damaged his leg so badly that it had to be amputated after the accident. Having a leg amputated, he was really depressed for months.

C. When the doctors had to amputate his leg, he did not let the loss of his leg keep him from participating in sports. Even with one foot, because his other leg was amputated, he was a very successful sportsman.

Amputate

3. A. How can you be so apathetic about the world and its problems? Don't you have emotion?

B. Some people are so apathetic that they do not pay attention to things which happen in the society. Maybe they think that when they are apathetic they can live more happily.

C. Parents are becoming apathetic about their children's education and show little interest in it. If parents become so apathetic about their children's education and do not care whether their children study well or not, in the near future we will have universities filled with unqualified students.

Apathetic

4. A. His explanations about the problematic situation resulted only in befuddling her more.

B. I understand the text but the numbers are befuddling me. I think the numbers and the text are explaining different things; that is why the numbers are befuddling.

C. I don't know why but the explanations about the lesson just befuddled me. As he continued explaining the lesson to me I felt I was getting more and more befuddled and could understand nothing.

Befuddling

5. A. He would brook no criticism, even from his beloved daughter

B. I cannot brook any noise when I am studying. Because I cannot brook any noise while I am studying and get distracted even with a little noise, I usually study at the library which is so quiet.

C. Sometimes, it is very difficult to brook long hours of work. He used to work from 8 a.m. to 6 p. m. but he could not brook the long hours anymore, and got very tired. Finally he changed his job.

Brook .............. 
6. A. In the capacious areas of the railroad terminal, thousands of travelers were waiting for their trains

B. It is a capacious theater; hundreds of people can come and watch different plays. The theatre is capacious, so it is never completely filled even on holydays with hundreds of people.

C. The party was in a capacious house in the north of Tehran and about 600 people were invited. The house was so capacious that about half of the guests stayed the night there and went back to their homes the next morning.

Capacious

7. A. Ali was fired from work and was very despondent.

B. Sarah lost her father a year ago in an accident, but she is still despondent. When Sarah lost her father, she was so despondent that she could not eat food for two or three days.

C. When Ahmad could not pass the university entrance exam he got very despondent and broke the window of his room. Even one year after the exam he was despondent and could not forget the memory of his failure and decided not to study anymore. He is working in a factory at the moment.

Despondent

8. A. He is very good at playing roles; he can feign any feeling like sadness, happiness, and surprise.

B. She had an exam and was not ready; therefore, she decided to feign illness and stay at home. The next day that she went to school, she still had to feign that she is sick and had not recovered fully.

C. My parents wanted to throw a surprise birthday party for me but I knew it in advance, so I decided to feign that I did not know. On the birthday when I came back from university I feigned surprise to make my parents happy.

Feign .............

9. A. It is a very onerous job to work from 8 in the morning till 10 in the evening.

B. He always complained that his job was so onerous and he had to do a lot from 8 a. m. to 6 p.m. Last month he asked for an assistant because his work load was too onerous and he could not do it alone, for example he had to answer a lot of phone calls, write many emails and supervise workers in the factory all by himself.

C. Giving a lot of homework to students will make their task at home too onerous and this, in turn, may result in their losing motivation. Teachers should be very careful not to make students' homework onerous in order to keep them interested.

Onerous

10. A. After an argument, the upshot was that they all agreed to help her pay back her debt

B. The upshot of the interview was that he could work in the company for another year.

Another upshot was that if during this year he worked well, he would be an official member of the company; otherwise he had to leave after a year.

C. The upshot of that experience was that I decided to quit university and forget studying medicine, because I saw a lot of blood in the hospital and I did not like blood. Another upshot was that I decided to start working as a businessman, since in this way I can make more money and it is more interesting than studying.

Upshot .............

11. A. The ultimate champion of the boxing competition will be clear tonight, because tonight is the final match.

B. The ultimate failure of the project shocked all the researchers in the company. The researchers concluded that the ultimate outcome of the experiment could not be predicted.

C. The ultimate goal of the students was to pass university entrance exam and study at university. They also wanted to study until the ultimate degree at university which is $\mathrm{Ph} . \mathrm{D}$.

Ulimate .............

12. A. He is really voluble. He can talk for hours without stopping.

B. Some people believe that it is rude to be voluble, because when a person is voluble, other people cannot find time to talk.

C. One of my friends is vey voluble, when he starts talking, everybody knows that he will continue for a long time. Although he accepts that he is voluble, he cannot do anything about it because he believes that it has become a habit for him.

Voluble

13. A. She was absolutely livid that he had lied to her.

B. He was so livid that he tore the letter and started shouting. Later, when I asked him why he got livid, he answered that there was something insulting in the letter that made him lose his control.

C. When I looked at him, I saw his face was red and I understood that he was livid, but I did not know why. He said that he had a fight with his boss and he might get fired from his job which made him livid.

Livid ....

14. A. Many people loathe the smell of fish and cannot tolerate it.

B. Some men loathe shopping, because it makes them really tired to walk from one store to another. But most of women are in love with shopping and cannot understand why some men loathe it.

C. I really loathe it when people make promises and don't keep them. I think when somebody makes a promise he has to keep it. I also loathe it when people lie. I think when people lie to you, they are insulting you.

loathe .

15. A. What vexed him most was that nobody had apologized to him, although he was right and others had made a mistake.

B. It vexes me that Kim never returns the books she borrows. And what vexes me more is that I have asked her several times to return the books she has borrowed, and each time she says: "ok", but she does not.

C. Ahmad has a very vexing habit of interrupting others while they are talking. Whenever I explain to him that what he does is wrong he stops doing it for some time, but after some days he starts over his vexing habit and starts talking while others are not finished yet.

Vex ............ 
Farahanynia, M., \& Nasiri, M.

16. A. Hossein is a very tenacious person; he tries his best to achieve what he wants, even if is so difficult.

B. Right two months before his university entrance exam, his father died, but because he is a tenacious person he did not stop studying and passed the exam successfully. When people asked him how he could pass the exam in such a difficult time, he said the only secret to success is tenacity.

C. He is a very tenacious doctor and tries his best to do an operation successfully. Once in an operation, things went wrong and all the other doctors were disappointed, but since he was very tenacious he did not give up and saved the patient.

Tenacity

17. A. In the war between Iran and Iraq a lot of houses were obliterated in the south west of Iran.

B. Many Japanese people's houses were obliterated after the latest earthquake and they became homeless. What made it even worse was that their factories and roads were obliterated by tsunami.

C. The killer took the dead body to the garden and wanted to bury it, but he thought the police may find the grave, then he obliterated the body by burning it. Despite his entire attempt to obliterate any evidence of the murder, the killer was caught, because the detective was Sherlock Holmes.

Obliterate

18. A. She's too parsimonious to give money to charity.

B. Usually when people get old, they become parsimonious and love money, and some old people become even too parsimonious to spend money for their medicine.

C. Ali is a very rich person, some people say that it is because he is a parsimonious person and just saves his money. Ali thinks differently and believes that not only is he not parsimonious but also he is a very generous person and spends a lot of money and he is rich because he works a lot.

Parsimonious

19. A. As I drove home, I tried to think how I was going to pacify my wife, who was angry with my decision about not going to her parents' for dinner.

B. He had a fight with his boss and was angry. I wanted to talk to him and pacify him, but as I started to talk I understood he was too angry to be pacified by talking, then I left him alone for a while. Sometimes the only thing which is needed to calm down is time. C. Kamran's wife passed away two months ago, and nothing has pacified his deep sadness since that time. My friends and I have tried to pacify him by taking him out and talking to him but nothing has worked.

Pacify

20. A. The president is chosen by people from among contenders.

B. First some movies are chosen as contenders for Oscar, and then from among the contenders, one of them is chosen as the best one to get the Oscar.

C. Parviz Parastuee was a contender for the best actor. But someone else was chosen as the best actor from among the contenders.

Contender 